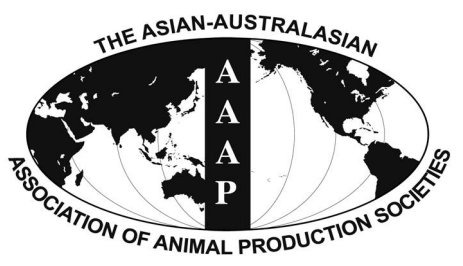

Open Access

Asian Australas. J. Anim. Sci.

Vol. 29, No. 12 : 1782-1789 December 2016

http://dx.doi.org/10.5713/ajas.15.1016

Www.ajas.info

pISSN 1011-2367 elSSN 1976-5517

\title{
Quality of Meat (Longissimus dorsi) from Male Fallow Deer (Dama dama) Packaged and Stored under Vacuum and Modified Atmosphere Conditions
}

\author{
N. Piaskowska*, T. Daszkiewicz, D. Kubiak, and P. Zapotoczny ${ }^{1}$ \\ Department of Commodity Science and Animal Raw Material Processing, \\ University of Warmia and Mazury in Olsztyn, Oczapowskiego 5, 10-719 Olsztyn, Poland
}

\begin{abstract}
This study evaluated the effect of vacuum and modified atmosphere $\left(40 \% \mathrm{CO}_{2}+60 \% \mathrm{~N}_{2}, \mathrm{MA}\right)$ packaging on the chemical composition, physicochemical properties and sensory attributes of chill-stored meat from 10 fallow deer (Dama dama) bucks at 17 to 18 months of age. The animals were hunter-harvested in the forests of north-eastern Poland. During carcass dressing ( 48 to $54 \mathrm{~h}$ post mortem), both musculus longissimus muscles were cut out. Each muscle was divided into seven sections which were allocated to three groups: 0, A, and B. Samples 0 were immediately subjected to laboratory analyses. Samples A were vacuum-packaged, and samples B were packaged in MA. Packaged samples were stored for 7, 14, and 21 days at $2^{\circ} \mathrm{C}$. The results of the present study showed that the evaluated packaging systems had no significant effect on the quality of fallow deer meat during chilled storage. However, vacuum-packaged meat samples were characterised by greater drip loss. Vacuum and MA packaging contributed to preserving the desired physicochemical properties and sensory attributes of meat during 21 days of storage. Regardless of the packaging method used, undesirable changes in the colour, water-holding capacity and juiciness of meat, accompanied by tenderness improvement, were observed during chilled storage. (Key Words: Wild Fallow Deer, Vacuum, Modified Atmosphere, Storage Time, Meat Quality)
\end{abstract}

\section{INTRODUCTION}

Due to their chemical composition and specific properties, meat products have limited durability. Cold storage allows to slow down undesirable qualitative changes in meat. However, fresh unpackaged meat suffers considerable weight and quality losses by evaporation and drying during prolonged storage periods. Undesirable changes in meat colour, lipid oxidation and the growth of bacterial microflora are also observed. Thus, the basic purpose of packaging is to protect meat from the above undesirable impacts, extend its shelf-life and facilitate distribution (Zhou et al., 2010).

Vacuum packaging and modified atmosphere (MA)

\footnotetext{
* Corresponding Author: N. Piaskowska. Tel: +48-895233833, Fax:+48-895233833, E-mail: natalka3007@wp.pl

${ }^{1}$ Department of System Engineering, University of Warmia and Mazury in Olsztyn, Heweliusza 14, 10-718 Olsztyn, Poland.

Submitted Dec. 13, 2015; Revised Mar. 17, 2016; Accepted Apr. 2, 2016
}

packaging are popular techniques used in the food processing industry. Vacuum packaging prevents the proliferation of aerobic bacteria and slows down the rate of undesirable changes in the chemical composition and sensory properties of meat and meat products (Jeremiah, 2001). The disadvantages of vacuum packaging of meat include relatively high drip loss and colour darkening, which are regarded as unattractive from the consumer's perspective (Hur et al., 2013). An alternative to vacuum packaging is MA packaging where the composition and proportion of gases are largely dictated by meat type. In MA packaging of meat, the gas mixture usually contains $\mathrm{CO}_{2}$-which inhibits the growth of anaerobic microorganisms, $\mathrm{N}_{2}$ - which is a neutral filler gas, and $\mathrm{O}_{2}-$ which preserves the bright-red colour of oxygenated myoglobin (oxymyoglobin) in beef (Jeremiah, 2001).

The influence of packaging method and storage time on the quality of meat from slaughter animals has been investigated in numerous studies, whereas very few 
publications address wild game meat from free-living animals, including fallow deer. Therefore, the aim of this study was to determine the effect of vacuum and MA (40\% $\mathrm{CO}_{2}+60 \% \mathrm{~N}_{2}, \mathrm{MA}$ ) packaging on the chemical composition, physicochemical properties and sensory attributes of chillstored meat from wild fallow deer bucks.

\section{MATERIALS AND METHODS}

\section{Animals and sample collection}

The experimental materials comprised samples of Longissimus dorsi (LD) collected from 10 fallow deer (Dama dama) bucks at 17 to 18 months of age. The animals were hunter-harvested in the forests of north-eastern Poland (Sępopol Plain, Region of Warmia, and Mazury) during one hunting season, in November and December. The age of bucks was determined based on the information provided by hunters.

The carcasses were transported to a meat processing plant. The time that passed from the harvest of animals to carcass cutting was 48 to 54 hours. All carcasses were characterised by: no bullet damage to the LD muscle region; no contamination due to damage to the digestive tract (bullet damage or incorrect evisceration procedure); $\mathrm{pH}$ of the LD muscle (measured in the left muscle, behind the last rib) in the range of 5.4 to 5.8 .

The LD muscles were cut out of the left and right side of each carcass, they were packaged in polyethylene bags and transported to the laboratory in containers with ice. In the laboratory, the muscles from each carcass were divided into 7 parts of similar weight, which were allocated to three groups: 0, A, B. Samples 0 were subjected to laboratory analysis immediately (ca. 52 to 54 hours from the harvest of animals), samples A were vacuum-packaged, and samples B were packaged under MA with the following gas mixture composition: $40 \% \mathrm{CO}_{2}+60 \% \mathrm{~N}_{2}$. Packaging was carried out with a packaging machine (Model PP-5MG (015), TEPRO, Koszalin, Poland) using barrier bags made of ethylene-vinyl alcohol copolymer with gas permeability: $\mathrm{O}_{2}=1 \mathrm{~cm}^{3} / \mathrm{m}^{2} / 24$ $\mathrm{h} / \mathrm{bar} / 23^{\circ} \mathrm{C}, \quad \mathrm{N}_{2}<0.1 \mathrm{~cm}^{3} / \mathrm{m}^{2} / 24 \mathrm{~h} / \mathrm{bar} / 23^{\circ} \mathrm{C}, \quad \mathrm{CO}_{2}=1.6$ $\mathrm{cm}^{3} / \mathrm{m}^{2} / 24 \mathrm{~h} / \mathrm{bar} / 23^{\circ} \mathrm{C}, \mathrm{H}_{2} \mathrm{O}=3 \mathrm{~g} / \mathrm{m}^{2} / 24 \mathrm{~h} / 23^{\circ} \mathrm{C}$. Packaged samples $\mathrm{A}$ and $\mathrm{B}$ were stored for 7,14 , and 21 days at $2^{\circ} \mathrm{C}$. Non-stored (0) and stored (A and B) samples were analysed at the laboratory to determine meat quality.

\section{Chemical measurements}

The analysis of the proximate chemical composition of meat included the determination of (AOAC, 1990): dry matter content (by drying at $105^{\circ} \mathrm{C}$ to constant weight), total protein content by the Kjeldahl method (Kjeltec 2200 Auto Distillation Unit, FOSS Analytical, Hilleroed, Denmark), crude fat content by Soxhlet extraction with diethyl ether as the solvent (Soxtec 2050 Auto Fat
Extraction System, FOSS Analytical, Denmark), and ash content by incineration at $550^{\circ} \mathrm{C}$ to constant weight.

The rate of muscle protein proteolysis was determined based on the content of total nitrogen and non-protein nitrogen (Kjeldahl method) in water extracts of meat prepared as described by Herring et al. (1971), after trichloroacetic acid precipitation of proteins. Protein nitrogen content was calculated as the difference between total nitrogen and non-protein nitrogen.

\section{Physicochemical properties}

Before carcass cutting, the $\mathrm{pH}$ of the LD muscle was measured behind the last rib to eliminate dark, firm, and dry meat, with the use of a combination Double Pore electrode (Hamilton Bonaduz, Bonaduz, Switzerland) and a pH 340i $\mathrm{pH}$-meter equipped with a TFK 150/E temperature sensor (WTW Wissenschaftlich-Technische Werkstätten, Weilheim, Germany). The $\mathrm{pH}$ of meat was measured in the laboratory, in water homogenates ( $10 \mathrm{~g}$ of meat was homogenized with $10 \mathrm{~cm}^{3}$ of redistilled water using an IKA Ultra Turrax T25 digital homogenizer - IKA-Werke, Staufen, Germany) at a rotational frequency about $104 \mathrm{~Hz}$ with $3 \times 5 \mathrm{~s}$ bursts, with the use of a combination Polilyte Lab electrode (Hamilton Bonaduz, Switzerland) and an inoLab Level $2 \mathrm{pH}$-meter equipped with a TFK 325 temperature sensor (WTW Wissenschaftlich-Technische Werkstätten, Germany).

The rate of lipid oxidation was estimated based on thiobarbituric-acid-reactive substances (TBARS) value (Pikul et al., 1989). Absorbance was measured using a Specord 40 spectrophotometer (Analytik Jena, Jena, Germany) at a wavelength of $532 \mathrm{~nm}$. TBARS values expressed as milligrams of malondialdehyde (MDA) per kilogram of meat.

Meat colour was determined based on the values of CIELAB coordinates, $L^{*}$ (lightness), $a^{*}$ (redness) and $b^{*}$ (yellowness) (CIE, 1978). The colour space parameters $L^{*}$, $a^{*}$ and $b^{*}$ were measured three times using a HunterLab MiniScan XE Plus spectrocolorimeter (Hunter Associates Laboratory, Reston, VA, USA) with standard illuminant D65, a $10^{\circ}$ standard observer angle and a $2.54-\mathrm{cm}$-diameter aperture, at different points over the muscle cross-section area. Prior to the measurement, samples wrapped in oxygen-permeable and water-impermeable foil were stored for $0.5 \mathrm{~h}$ at $4^{\circ} \mathrm{C}$. The value of parameter $\mathrm{C}^{*}$ (chroma) was calculated from the formula:

$$
\mathrm{C}^{*}=\left(\mathrm{a}^{* 2}+\mathrm{b}^{* 2}\right)^{1 / 2}
$$

The water-holding capacity of meat was determined based on natural drip loss (Honikel, 1998), forced drip loss - by the Grau and Hamm method (Van Oeckel et al., 1999), cooking loss (Honikel, 1998) and the ability to bind added water - by the method proposed by Dzierżyńska-Cybulko 
(1963). Minced and chilled $\left(4^{\circ} \mathrm{C}, 1 \mathrm{~h}\right)$ meat samples $(10 \mathrm{~g})$ were homogenized with $20 \mathrm{~cm}^{3}$ distilled water at $4^{\circ} \mathrm{C}$. The homogenate was left at $4^{\circ} \mathrm{C}$ for $30 \mathrm{~min}$., and next it was centrifuged at $3,500 \times \mathrm{g}$ for $10 \mathrm{~min}$. After centrifugation, the water that was not bound by meat was poured out, and the test tube was placed on a piece of filter paper upside down to dry. The test tube was weighed after $5 \mathrm{~min}$. The amount of water bound by meat was determined as the difference between sample weight before homogenization and centrifugation and after centrifugation.

\section{Sensory analysis}

The sensory properties of cooked meat were evaluated by five trained panellists, previously selected for their flavour and texture sensitivity (ISO, 1993). Prior to sample evaluation, the panellists participated in orientation sessions to familiarize themselves with the sensory properties of cooked fallow deer meat. Cooked beef loin was used as a standard reference for comparison with game meat during the training of the panel. Numerical scaling (5-point scale) was used to express the intensity and desirability of traits (Daszkiewicz et al., 2012). The panellists were trained for a period of three months, during 1-h sessions, three times a week (36 h in total). Meat was cooked (Baryłko-Pikielna et al., 1964) in a $6 \mathrm{~g} / \mathrm{kg} \mathrm{NaCl}$ solution (meat to solution weight ratio of $1: 2$ ) at $96^{\circ} \mathrm{C} \pm 2^{\circ} \mathrm{C}$. The ultimate temperature inside the sample was $80^{\circ} \mathrm{C}$. Approximately $1 \mathrm{~cm} \times 1 \mathrm{~cm} \times 1 \mathrm{~cm}$ cubes of meat were cut from the middle of each cooked sample and wrapped in aluminium foil. Coded meat samples were presented to the panellists at room temperature. Distilled water was made available to the panellists for mouth cleansing between samples. All sensory attributes (aroma, taste, juiciness, and tenderness) of each sample were evaluated during a single session. A maximum of five meat samples were assessed per session. The panellists used a 5 - point hedonic scale (1 point - the worse, 5 points - the best) to express the intensity and desirability of traits (Daszkiewicz et al., 2012)

\section{Shear force measurement}

The maximum shear force of meat ( 5 samples, cylinders $1.27 \mathrm{~cm}$ in diameters and $2 \mathrm{~cm}$ in height) was determined using a Warner-Bratzler head (500 N, speed $100 \mathrm{~mm} / \mathrm{min}$.) attached to an INSTRON 5542 universal testing machine (Instron, Canton, MA, USA). The preparation of meat samples and the measurement of shear force were performed as described by Honikel (1998).

\section{Statistical analysis}

To determine differences in the proximate chemical composition, physicochemical properties and sensory attributes of LD muscle samples stored under vacuum and MA, the results were analysed statistically in the STATISTICA ver. 10 application (StatSoft, Tulsa, OK, USA) using one-way analysis of variance. The statistical significance of differences between group means was determined by Duncan's multiple range test at a significance level of $\mathrm{p} \leq 0.05$.

\section{RESULTS AND DISCUSSION}

\section{Weight loss}

The time of cold storage had no significant $(\mathrm{p}>0.05)$ effect on weight loss in LD muscle samples (Table 1), but weight loss tended to increase over the aging period. Vacuum-packaged samples were characterised by greater $(\mathrm{p} \leq 0.05)$ weight loss than samples packaged under MA composed of $40 \% \mathrm{CO}_{2}+60 \% \mathrm{~N}_{2}$. After 7,14 , and 21 days of storage, the differences between mean values in groups reached $1.31,1.93$, and 1.64 percentage points, respectively.

Some drip losses of chill-stored packaged meat, leading to weight losses, are natural and cannot be avoided (HuffLonergan and Lonergan, 2005). Drip loss may modify the chemical composition and moisture-related properties of

Table 1. Meat weight losses and proximate chemical composition of meat after modified atmosphere storage

\begin{tabular}{lcrrrr}
\hline \multirow{2}{*}{ Parameter } & \multirow{2}{*}{ Modified atmosphere } & \multicolumn{4}{c}{ Storage time $(\mathrm{d})$} \\
\cline { 3 - 6 } & & 0 & 7 & \multicolumn{1}{c}{14} & 21 \\
\hline Weight loss $(\%)$ & Vacuum & - & $3.17 \pm 0.85^{\mathrm{x}}$ & $3.97 \pm 0.99^{\mathrm{x}}$ & $4.02 \pm 0.90^{\mathrm{x}}$ \\
& $40 \% \mathrm{CO}_{2}+60 \% \mathrm{~N}_{2}$ & - & $1.86 \pm 0.33^{\mathrm{y}}$ & $2.04 \pm 0.41^{\mathrm{y}}$ & $2.38 \pm 0.82^{\mathrm{y}}$ \\
Dry matter content $(\mathrm{g} / \mathrm{kg})$ & $\mathrm{Vacuum}$ & $258.10 \pm 3.90$ & $255.20 \pm 4.30$ & $255.50 \pm 3.90$ & $255.70 \pm 3.60$ \\
& $40 \% \mathrm{CO}_{2}+60 \% \mathrm{~N}_{2}$ & $258.10 \pm 3.90$ & $255.90 \pm 5.00$ & $255.00 \pm 2.40$ & $255.70 \pm 2.70$ \\
Total protein content $(\mathrm{g} / \mathrm{kg})$ & $\mathrm{Vacuum}$ & $228.40 \pm 3.60$ & $228.60 \pm 4.00$ & $226.20 \pm 2.80$ & $228.10 \pm 6.80$ \\
& $40 \% \mathrm{CO}_{2}+60 \% \mathrm{~N}_{2}$ & $228.40 \pm 3.60$ & $229.40 \pm 3.70$ & $228.10 \pm 2.60$ & $229.10 \pm 4.10$ \\
Fat content $(\mathrm{g} / \mathrm{kg})$ & $\mathrm{Vacuum}$ & $5.20 \pm 1.40$ & $4.10 \pm 2.10^{\mathrm{a}}$ & $4.90 \pm 2.30$ & $6.50 \pm 1.60^{\mathrm{b}}$ \\
& $40 \% \mathrm{CO}_{2}+60 \% \mathrm{~N}_{2}$ & $5.20 \pm 1.40$ & $4.50 \pm 1.80^{\mathrm{a}}$ & $4.60 \pm 1.70^{\mathrm{a}}$ & $6.90 \pm 2.40^{\mathrm{b}}$ \\
Ash content $(\mathrm{g} / \mathrm{kg})$ & $\mathrm{Vacuum}$ & $11.30 \pm 0.70^{\mathrm{a}}$ & $10.40 \pm 0.50^{\mathrm{bc}}$ & $11.00 \pm 0.30^{\mathrm{ac}}$ & $10.60 \pm 0.30^{\mathrm{c}}$ \\
& $40 \% \mathrm{CO}_{2}+60 \% \mathrm{~N}_{2}$ & $11.30 \pm 0.70^{\mathrm{a}}$ & $10.80 \pm 0.50$ & $10.80 \pm 0.50$ & $10.70 \pm 0.30^{\mathrm{b}}$ \\
\hline
\end{tabular}

Values represent mean \pm standard deviation.

${ }^{a-c}$ Values in the same row followed by different letters are significantly different $(p \leq 0.05)$.

${ }^{\mathrm{x}-\mathrm{y}}$ Values in the same column followed by different letters are significantly different $(\mathrm{p} \leq 0.05)$. 
meat. High losses of fluid in the form of drip may also negatively affect consumer appeal. The compounds present in juice from raw packaged meat are easily degraded, leading to undesirable changes in the colour and aroma of meat.

In our study, drip loss was greater in vacuum-packaged meat samples than in MA-packaged samples, which was also observed by other authors (Cayuela et al., 2004; Sekar et al., 2006). According to Sørheim et al. (2004), this may be due to the mechanical impact of reduced pressure on vacuum-packaged meat. The same authors also demonstrated that in MA-packaged meat, the amount of drip can be influenced by the $\mathrm{CO}_{2}$ content of the mixture, if the gas is used at high concentrations. When $\mathrm{CO}_{2}$ dissolves in water, it is partially converted into carbonic acid $\mathrm{H}_{2} \mathrm{CO}_{3}$, which may lower the $\mathrm{pH}$ of meat and bring it closer to the isoelectric point of proteins. As proteins get closer to their isoelectric point, they tend to bind less water (HuffLonergan and Lonergan, 2005).

\section{Chemical composition of meat}

The packaging method and storage time had no significant $(\mathrm{p}>0.05)$ effect on the average dry matter and total protein content of LD muscle samples (Table 1). Statistically significant differences were found in the crude fat and ash content of LD muscle samples stored for different periods of time (Table 1). Meat samples stored for 21 days had the highest fat content; in vacuum-packaged samples, it was significantly $(\mathrm{p} \leq 0.05)$ higher than that noted after 7 days of storage, whereas in MA-packaged samples, it was significantly $(\mathrm{p} \leq 0.05)$ higher than that observed after 7 and 14 days. Ash content was lower in stored meat samples than in non-stored samples, but the noted differences, although statistically significant, were very small.

The absence of significant changes in the dry matter content of LD muscle samples during chilled storage, despite the observed drip loss, could result from the combined effect of various factors. Water loss from meat should be accompanied by an increase in dry matter concentrations, but this process could be limited by the loss of water-soluble compounds, mostly proteins (HuffLonergan and Lonergan, 2005). The differences in the proximate chemical composition of the analysed samples before and after storage could also result from natural variations in the chemical composition of the LD muscle.

Intense proteolysis of proteins during post-mortem aging leads to the formation of low-molecular weight compounds, which may have a negative influence on the flavour, aroma and water-holding capacity of meat (Feidt et al., 1998). In our study, the analysed packaging systems had no significant $(p>0.05)$ effect on the percentages of watersoluble nitrogen compounds in total nitrogen in meat and the percentages of nitrogen fractions in water extracts of meat (Table 2). The latter were affected by the time of chilled storage. In comparison with non-stored samples, stored meat and its water extract were characterised by a higher percentage of non-protein nitrogen, which increased over the aging period at the expense of protein nitrogen. The noted differences were statistically significant.

There is a scarcity of data on the proteolysis of proteins in fallow deer meat, which could be used as reference values in our study. Tešanović et al. (2011) reported a steady increase in the non-protein nitrogen content of LD muscle samples collected from three-year-old wild fallow deer and subjected to aging (the authors provided no information on the sex of animals or aging conditions). In the cited study, the non-protein nitrogen content of the LD muscle was $0.36 \% 24$ hours postmortem, and it increased to $0.42 \%$ after 30 days of aging.

\section{pH value}

The $\mathrm{pH}$ of LD muscle samples increased during storage (Table 3), but the noted changes in acidity were small. The difference between the highest (after 21 days of storage) and the lowest (non-stored samples) average $\mathrm{pH}$ values

Table 2. Nitrogen fractions in meat after modified atmosphere storage

\begin{tabular}{|c|c|c|c|c|c|}
\hline \multirow{2}{*}{ Parameter } & \multirow{2}{*}{$\begin{array}{l}\text { Modified } \\
\text { atmosphere }\end{array}$} & \multicolumn{4}{|c|}{ Storage time (d) } \\
\hline & & 0 & 7 & 14 & 21 \\
\hline \multirow{2}{*}{$\begin{array}{l}\text { The ratio between total } \mathrm{N} \text { of water-soluble compounds } \\
\text { and total } \mathrm{N} \text { in in meat }(\%)\end{array}$} & Vacuum & $28.91 \pm 2.15$ & $29.18 \pm 1.43$ & $29.62 \pm 1.30$ & $29.02 \pm 2.26$ \\
\hline & $40 \% \mathrm{CO}_{2}+60 \% \mathrm{~N}_{2}$ & $28.91 \pm 2.15$ & $29.07 \pm 1.80$ & $29.38 \pm 1.99$ & $29.27 \pm 1.99$ \\
\hline \multirow{2}{*}{$\begin{array}{l}\text { The ratio between } \mathrm{N} \text { of water-soluble protein } \\
\text { compounds and total } \mathrm{N} \text { in meat }(\%)\end{array}$} & Vacuum & $15.37 \pm 1.52^{\mathrm{a}}$ & $14.77 \pm 0.71$ & $14.73 \pm 0.93$ & $13.82 \pm 1.41^{\mathrm{b}}$ \\
\hline & $40 \% \mathrm{CO}_{2}+60 \% \mathrm{~N}_{2}$ & $15.37 \pm 1.52^{\mathrm{a}}$ & $15.02 \pm 1.33$ & $14.86 \pm 1.35$ & $13.76 \pm 0.95^{\mathrm{b}}$ \\
\hline \multirow{2}{*}{$\begin{array}{l}\text { The ratio between } \mathrm{N} \text { of water-soluble non-protein } \\
\text { compounds and total } \mathrm{N} \text { in meat }(\%)\end{array}$} & Vacuum & $13.54 \pm 0.93^{\mathrm{a}}$ & $1 \pm 1.01$ & $14.89 \pm 1.03^{\mathrm{b}}$ & $15.20 \pm 1.38^{\mathrm{b}}$ \\
\hline & $40 \% \mathrm{CO}_{2}+60 \% \mathrm{~N}_{2}$ & $13.54 \pm 0.93^{\mathrm{a}}$ & $14.05 \pm 0.65^{\mathrm{ab}}$ & $14.53 \pm 0.71^{\mathrm{b}}$ & $15.50 \pm 1.26^{\mathrm{c}}$ \\
\hline \multirow{2}{*}{$\begin{array}{l}\text { The ratio between } \mathrm{N} \text { of water-soluble protein } \\
\text { compounds and total } \mathrm{N} \text { of water-soluble compounds (\%) }\end{array}$} & Vacuum & $53.11 \pm 2.11^{\mathrm{a}}$ & $50.64 \pm 1.68^{\mathrm{bc}}$ & $49.74 \pm 2.42^{\mathrm{bd}}$ & $47.59 \pm 2.93^{\mathrm{d}}$ \\
\hline & $40 \% \mathrm{CO}_{2}+60 \% \mathrm{~N}_{2}$ & $53.11 \pm 2.11^{\mathrm{a}}$ & $51.61 \pm 1.78^{\mathrm{ab}}$ & $50.49 \pm 1.47^{\mathrm{b}}$ & $47.06 \pm 1.58^{\mathrm{c}}$ \\
\hline \multirow{2}{*}{$\begin{array}{l}\text { The ratio between } \mathrm{N} \text { of water-soluble non-protein } \\
\text { compounds and total } \mathrm{N} \text { of water-soluble compounds (\%) }\end{array}$} & Vacuum & $46.89 \pm 2.11^{\mathrm{a}}$ & $49.36 \pm 1.68^{b c}$ & $50.26 \pm 2.42^{\mathrm{bd}}$ & $52.41 \pm 2.93^{\mathrm{d}}$ \\
\hline & $40 \% \mathrm{CO}_{2}+60 \% \mathrm{~N}_{2}$ & $46.89 \pm 2.11^{\mathrm{a}}$ & $48.39 \pm 1.78^{\mathrm{ab}}$ & $49.51 \pm 1.47^{\mathrm{b}}$ & $52.94 \pm 1.58^{\mathrm{c}}$ \\
\hline
\end{tabular}

\footnotetext{
Values represent mean \pm standard deviation.
}

${ }^{\mathrm{a}-\mathrm{c}}$ Values in the same row followed by different letters are significantly different $(\mathrm{p} \leq 0.05)$. 
Table 3. $\mathrm{pH}$, TBARS values and colour parameters of meat after modified atmosphere storage

\begin{tabular}{|c|c|c|c|c|c|}
\hline \multirow{2}{*}{ Parameter } & \multirow{2}{*}{ Modified atmosphere } & \multicolumn{4}{|c|}{ Storage time (d) } \\
\hline & & 0 & 7 & 14 & 21 \\
\hline \multirow[t]{2}{*}{$\overline{\mathrm{pH}}$} & Vacuum & $5.52 \pm 0.04^{\mathrm{a}}$ & $5.55 \pm 0.03^{\mathrm{a}}$ & $5.59 \pm 0.03^{\mathrm{b}}$ & $5.61 \pm 0.06^{\mathrm{b}}$ \\
\hline & $40 \% \mathrm{CO}_{2}+60 \% \mathrm{~N}_{2}$ & $5.52 \pm 0.04^{\mathrm{ab}}$ & $5.55 \pm 0.04^{\mathrm{b}}$ & $5.58 \pm 0.04^{\mathrm{bc}}$ & $5.61 \pm 0.07^{\mathrm{c}}$ \\
\hline \multirow[t]{2}{*}{ TBARS values (mg/kg) } & Vacuum & $0.76 \pm 0.11$ & $0.78 \pm 0.14$ & $0.70 \pm 0.15$ & $0.77 \pm 0.10$ \\
\hline & $40 \% \mathrm{CO}_{2}+60 \% \mathrm{~N}_{2}$ & $0.76 \pm 0.11$ & $0.83 \pm 0.18$ & $0.72 \pm 0.12$ & $0.82 \pm 0.13$ \\
\hline \multirow[t]{2}{*}{$L^{*}$} & Vacuum & $30.26 \pm 1.84^{\mathrm{a}}$ & $31.55 \pm 1.42$ & $31.99 \pm 1.42^{b}$ & $31.29 \pm 1.35$ \\
\hline & $40 \% \mathrm{CO}_{2}+60 \% \mathrm{~N}_{2}$ & $30.85 \pm 1.90$ & $31.30 \pm 1.70$ & $31.85 \pm 1.44$ & $31.51 \pm 1.35$ \\
\hline \multirow[t]{2}{*}{$a^{*}$} & Vacuum & $15.79 \pm 1.41$ & $17.10 \pm 1.37$ & $16.26 \pm 0.80$ & $16.33 \pm 2.26$ \\
\hline & $40 \% \mathrm{CO}_{2}+60 \% \mathrm{~N}_{2}$ & $16.28 \pm 1.58$ & $16.81 \pm 1.41$ & $16.32 \pm 3.15$ & $17.14 \pm 1.99$ \\
\hline \multirow[t]{2}{*}{$b^{*}$} & Vacuum & $10.58 \pm 1.44^{\mathrm{a}}$ & $12.29 \pm 1.41^{\mathrm{b}}$ & $11.98 \pm 0.90^{\mathrm{b}}$ & $11.22 \pm 1.93$ \\
\hline & $40 \% \mathrm{CO}_{2}+60 \% \mathrm{~N}_{2}$ & $11.14 \pm 1.69^{\mathrm{a}}$ & $14.44 \pm 6.57^{\mathrm{b}}$ & $12.05 \pm 1.96$ & $12.22 \pm 1.70$ \\
\hline \multirow[t]{2}{*}{$\mathrm{C}^{*}$} & Vacuum & $19.01 \pm 1.95^{\mathrm{a}}$ & $21.06 \pm 1.89^{\mathrm{b}}$ & $20.20 \pm 1.14$ & $19.82 \pm 2.92$ \\
\hline & $40 \% \mathrm{CO}_{2}+60 \% \mathrm{~N}_{2}$ & $19.73 \pm 2.25$ & $22.54 \pm 5.09$ & $20.30 \pm 3.57$ & $21.06 \pm 2.57$ \\
\hline
\end{tabular}

TBARS, thiobarbituric acid reactive substances expressed as milligrams of malondialdehyde per kilogram of meat.

Values represent mean \pm standard deviation.

${ }^{\mathrm{a}-\mathrm{c}}$ Values in the same row followed by different letters are significantly different $(\mathrm{p} \leq 0.05)$.

$L^{*}$, lightness; $a^{*}$, redness; $b^{*}$, yellowness; $\mathrm{C}^{*}$, chroma.

reached only 0.09 units. The significant differences between mean values within groups of vacuum-packaged and MApackaged samples resulted from low variation in $\mathrm{pH}$. The packaging technique had no significant $(\mathrm{p}>0.05)$ influence on the average $\mathrm{pH}$ values of meat samples stored for different periods of time (Table 3 ).

The minor changes in the average $\mathrm{pH}$ values of LD muscle samples, observed in the present study, do not correspond with the findings of Tešanović et al. (2011) who reported an increase in the average $\mathrm{pH}$ of fallow deer meat (LD muscle) during aging, from 5.58 on day 1 to 5.78 on day 15 , followed by a decrease to 5.48 on day 30 . A steady increase in the $\mathrm{pH}$ of chill-stored fallow deer meat, noted in our study, was associated with an increase in the content of alkaline compounds formed during autolysis (Feidt et al., 1998), but the effects of other factors on changes in meat acidity cannot be ruled out. Those factors probably include (microbiological analysis was not performed) a gradual increase in lactic acid content due to the growth of lactic acid bacteria (Hur et al., 2013) and the formation of $\mathrm{H}_{2} \mathrm{CO}_{3}$ in the aqueous phase of meat from $\mathrm{CO}_{2}$ contained in the gas mixture inside the MA package (Sørheim et al., 2004). Both processes could slow down alkalization due to proteolytic changes in muscle proteins.

\section{Thiobarbituric-acid-reactive substances values}

In this study, the packaging method and storage time had no significant ( $p>0.05$ ) effect on the MDA content of LD muscle samples (Table 3), which was relatively high at around $0.80 \mathrm{mg} / \mathrm{kg}$ meat.

The available literature provides scant information on lipid oxidation in chill-stored meat from wild animals. In our study, the average MDA content of fallow deer meat was higher than that noted by Wiklund et al. (2006) in red deer meat $(0.22$ to $0.45 \mathrm{mg} / \mathrm{kg})$, but lower than that reported by Cifuni et al. (2014) in fallow deer meat (3.58 to 5.61 $\mathrm{mg} / \mathrm{kg}$ ) and by Okabe et al. (2002) in sika deer (Cervus nippon) meat (above $6 \mathrm{mg} / \mathrm{kg}$ ). The high TBARS values in chill-stored fallow deer meat, determined in the present study, could be due to the presence of residual oxygen in the package, which contributes to lipid oxidation already at a content of $\leq 2 \%$ (Berruga et al., 2005). Wild game meat is also more prone to oxidation due to high content of unsaturated phospholipids and myoglobin, in particular heme-iron that acts as a prooxidant (Okabe et al., 2002).

\section{Meat colour}

The analysed packaging systems had no significant $(p>0.05)$ effect on the colour parameters of LD muscle samples (Table 3 ). No significant $(p>0.05)$ differences were found in the average values of colour parameters between samples stored for different periods of time. In comparison with non-stored samples, the colour of stored samples was slightly lighter $\left(L^{*}\right)$ (significant difference at $\mathrm{p} \leq 0.05$ in vacuum-packaged samples stored for 14 days) and had a significantly $(\mathrm{p} \leq 0.05)$ higher contribution of redness $\left(a^{*}\right)$. The contribution of the yellow component $\left(b^{*}\right)$ was significantly $(\mathrm{p} \leq 0.05)$ higher in MA-packaged samples stored for 7 days and in vacuum-packaged samples stored for 7 and 14 days, compared with non-stored samples. The differences in the values of colour components $\left(a^{*}\right.$ and, in particular, $\left.b^{*}\right)$ resulted in higher colour saturation $\left(\mathrm{C}^{*}\right)$ of stored LD muscle samples (Table 3).

Maintaining colour stability is one of the major problems associated with the optimization of meat storage conditions. Due to its higher susceptibility to oxidation, the meat of game animals is characterised by lower colour stability than other types of red meat (Farouk et al., 2007). 
Myoglobin and lipid oxidation interactions are of particular importance (Faustman et al., 2010). The products of fat degradation decrease oxymyoglobin redox stability and the probability of enzymatic metmyoglobin reduction, whereas heme-iron is a potent lipid prooxidant. Therefore, game meat, unlike beef, should not be packaged under MA with a high $\mathrm{O}_{2}$ content to preserve its colour.

Vacuum and MA packaging with the use of anaerobic gas mixtures does not prevent undesirable changes in the colour of wild game meat during chilled storage. Under industrial conditions, $\mathrm{O}_{2}$ cannot be completely removed from the vacuum or MA package, and low partial pressure of "residual oxygen" contributes to oxymyoglobin oxidation to metmyoglobin (Mancini and Hunt, 2005). In our study, the presence of "residual oxygen" inside the package was most probably responsible for the formation of metmyoglobin in chill-stored LD muscle samples, as indicated by higher values of colour parameter $b^{*}$ in stored samples, compared with non-stored samples.

\section{Water-holding capacity}

Storage conditions (vacuum, MA) had no significant ( $>0.05$ ) effect on the water-holding capacity of fallow deer meat (Table 4). An analysis of correlations between storage time and the water-holding capacity of LD muscle samples revealed that the amount of natural and forced drip loss tended to decrease in samples stored for 14 and 21 days, compared with those stored for 7 days (Table 4). Stored samples were also characterised by lower natural and forced drip loss than non-stored samples. A comparison of the ability to bind added water by LD muscle samples before and after chilled storage revealed a considerable increase in the water-holding capacity of meat stored for 7 days (Table 4). The ability to bind added water decreased steadily in meat stored for 14 and 21 days, particularly in vacuumpackaged samples (statistically significant differences between mean values in groups). The packaging method and storage time had no significant $(\mathrm{p}>0.05)$ influence on cooking loss in LD muscle samples (Table 4).
Changes in the water-holding capacity of meat during postmortem aging, observed in our study, resulted from autolytic degradation of cytoskeletal proteins (HuffLonergan and Lonergan, 2005). According to the cited authors, degradation of cytoskeletal proteins (desmin, talin, and vinculin) reduces the connections between the myofibrils and the sarcolemma, and between the myofibrils, which are involved in the transmission of longitudinal and lateral shrinkage of the myofibrils to the entire muscle cell during rigor mortis. Thus, water can move into the extracellular space where it is lost as drip. Proteolysis of the cytoskeletal framework of the muscle cell leads to the weakening of the sarcolemma, followed by expulsion of water from the extracellular space to the muscle cell. As a result, the water-holding capacity of meat increases to reach its second peak in ripened meat. The above observations were confirmed in our study where LD muscle samples stored for 7 days were characterised by the highest waterholding capacity. An improvement in the water-holding capacity of stored meat was also noted in measurements of natural and forced drip loss. However, our findings should be interpreted in view of both the changes in cytoskeletal proteins described above and the meat's water loss due to drip during chilled storage (Van Moeseke and De Smet, 1999). The water lost by meat immediately postmortem cannot be lost as drip at later stages of aging, which can create the impression of an apparent increase in the meat's water-holding capacity evaluated based on natural and forced drip loss.

\section{Sensory properties and shear force}

An analysis of the sensory properties of LD muscle samples showed that storage time had no significant $(p>0.05)$ effect on the intensity and desirability of their aroma and taste (Table 5). MA-packaged samples tended to have lower aroma intensity, but a significant $(\mathrm{p} \leq 0.05)$ difference between mean values in groups was noted only in samples stored for 14 days.

No significant $(p>0.05)$ changes were found in meat

Table 4. Evaluation of water-holding capacity of meat after modified atmosphere storage

\begin{tabular}{lccccc}
\hline \multirow{2}{*}{ Parameter } & \multirow{2}{*}{ Modified atmosphere } & \multicolumn{4}{c}{ Storage time (d) } \\
\cline { 3 - 6 } & & 0 & 7 & 14 & 21 \\
\hline Drip losses (\%) & Vacuum & $2.99 \pm 0.96^{\mathrm{a}}$ & $3.14 \pm 0.67^{\mathrm{a}}$ & $2.43 \pm 0.66$ & $2.24 \pm 0.58^{\mathrm{b}}$ \\
& $40 \% \mathrm{CO}_{2}+60 \% \mathrm{~N}_{2}$ & $2.99 \pm 0.96$ & $2.82 \pm 0.93$ & $2.30 \pm 0.58$ & $2.25 \pm 0.46$ \\
Water-holding capacity & Vacuum $^{2}$ & $5.31 \pm 0.80^{\mathrm{a}}$ & $4.64 \pm 0.96^{\mathrm{a}}$ & $3.52 \pm 0.36^{\mathrm{b}}$ & $3.68 \pm 1.00^{\mathrm{b}}$ \\
- Grau and Hamm method $\left(\mathrm{cm}^{2}\right)$ & $40 \% \mathrm{CO}_{2}+60 \% \mathrm{~N}_{2}$ & $5.31 \pm 0.80^{\mathrm{a}}$ & $4.54 \pm 0.88^{\mathrm{ab}}$ & $3.69 \pm 1.03^{\mathrm{bc}}$ & $3.58 \pm 1.05^{\mathrm{c}}$ \\
Cooking losses (\%) & Vacuum & $33.65 \pm 1.54$ & $33.59 \pm 1.43$ & $33.76 \pm 1.85$ & $33.68 \pm 1.38$ \\
Water-holding capacity & $40 \% \mathrm{CO}_{2}+60 \% \mathrm{~N}_{2}$ & $33.65 \pm 1.54$ & $33.51 \pm 0.82$ & $33.05 \pm 2.41$ & $33.98 \pm 0.89$ \\
- centrifugal method (\%) & Vacuum & $27.71 \pm 6.55^{\mathrm{a}}$ & $36.01 \pm 12.03^{\mathrm{b}}$ & $26.62 \pm 3.42^{\mathrm{a}}$ & $21.15 \pm 6.20^{\mathrm{a}}$ \\
\hline Values repumy & $40 \% \mathrm{CO}_{2}+60 \% \mathrm{~N}_{2}$ & $27.71 \pm 6.55$ & $34.29 \pm 10.40^{\mathrm{a}}$ & $25.66 \pm 3.89$ & $24.72 \pm 11.92^{\mathrm{b}}$ \\
\hline
\end{tabular}

Values represent mean \pm standard deviation.

${ }^{\mathrm{a}-\mathrm{c}}$ Values in the same row followed by different letters are significantly different $(\mathrm{p} \leq 0.05)$. 
Table 5. Sensory properties (points) and shear force $(\mathrm{N})$ of meat after modified atmosphere storage

\begin{tabular}{|c|c|c|c|c|c|}
\hline \multirow{2}{*}{ Parameter } & \multirow{2}{*}{ Modified atmosphere } & \multicolumn{4}{|c|}{ Storage time (d) } \\
\hline & & 0 & 7 & 14 & 21 \\
\hline \multirow[t]{2}{*}{ Aroma-intensity } & Vacuum & $4.00 \pm 0.79$ & $4.28 \pm 0.67$ & $4.50 \pm 0.56^{x}$ & $4.56 \pm 0.68$ \\
\hline & $40 \% \mathrm{CO}_{2}+60 \% \mathrm{~N}_{2}$ & $4.00 \pm 0.79$ & $3.67 \pm 0.66$ & $3.89 \pm 0.42^{\mathrm{y}}$ & $4.06 \pm 0.46$ \\
\hline \multirow[t]{2}{*}{ Aroma-desirability } & Vacuum & $4.89 \pm 0.22$ & $5.00 \pm 0.00$ & $5.00 \pm 0.00$ & $4.94 \pm 0.17$ \\
\hline & $40 \% \mathrm{CO}_{2}+60 \% \mathrm{~N}_{2}$ & $4.89 \pm 0.22$ & $5.00 \pm 0.00$ & $4.94 \pm 0.17$ & $5.00 \pm 0.00$ \\
\hline \multirow[t]{2}{*}{ Taste-intensity } & Vacuum & $4.17 \pm 0.35$ & $4.06 \pm 0.39$ & $4.17 \pm 0.25$ & $4.17 \pm 0.35$ \\
\hline & $40 \% \mathrm{CO}_{2}+60 \% \mathrm{~N}_{2}$ & $4.17 \pm 0.35$ & $4.00 \pm 0.35$ & $4.11 \pm 0.22$ & $4.00 \pm 0.00$ \\
\hline \multirow[t]{2}{*}{ Taste-desirability } & Vacuum & $4.83 \pm 0.25$ & $5.00 \pm 0.00$ & $5.00 \pm 0.00$ & $4.89 \pm 0.22$ \\
\hline & $40 \% \mathrm{CO}_{2}+60 \% \mathrm{~N}_{2}$ & $4.83 \pm 0.25$ & $5.00 \pm 0.00$ & $4.94 \pm 0.17$ & $4.89 \pm 0.22$ \\
\hline \multirow[t]{2}{*}{ Juiciness } & Vacuum & $4.00 \pm 0.50^{\mathrm{a}}$ & $3.72 \pm 0.57$ & $3.72 \pm 0.36$ & $3.44 \pm 0.30^{\mathrm{b}}$ \\
\hline & $40 \% \mathrm{CO}_{2}+60 \% \mathrm{~N}_{2}$ & $4.00 \pm 0.50$ & $3.78 \pm 0.62$ & $3.94 \pm 0.30$ & $3.67 \pm 0.35$ \\
\hline \multirow[t]{2}{*}{ Tenderness } & Vacuum & $3.83 \pm 0.56^{\mathrm{a}}$ & $4.11 \pm 0.33$ & $4.22 \pm 0.57$ & $4.61 \pm 0.70^{\mathrm{b}}$ \\
\hline & $40 \% \mathrm{CO}_{2}+60 \% \mathrm{~N}_{2}$ & $3.83 \pm 0.56^{\mathrm{a}}$ & $4.22 \pm 0.44^{\mathrm{b}}$ & $4.33 \pm 0.25^{\mathrm{b}}$ & $4.89 \pm 0.22^{\mathrm{c}}$ \\
\hline \multirow[t]{2}{*}{ Shear force } & Vacuum & $22.95 \pm 5.70$ & $20.91 \pm 6.85$ & $18.85 \pm 5.90$ & $18.06 \pm 3.48$ \\
\hline & $40 \% \mathrm{CO}_{2}+60 \% \mathrm{~N}_{2}$ & $22.95 \pm 5.70^{\mathrm{a}}$ & $20.12 \pm 3.19$ & $18.60 \pm 2.56^{\mathrm{b}}$ & $17.89 \pm 1.41^{\mathrm{b}}$ \\
\hline
\end{tabular}

Values represent mean \pm standard deviation.

${ }^{a-c}$ Values in the same row followed by different letters are significantly different $(p \leq 0.05)$.

${ }^{\mathrm{x}-\mathrm{y}}$ Values in the same column followed by different letters are significantly different $(\mathrm{p} \leq 0.05)$.

juiciness at successive stages of chilled storage (Table 5), but stored samples were characterised by lower juiciness than non-stored samples (statistically significant difference was observed between non-stored samples and vacuumpackaged samples stored for 21 days). The packaging system (vacuum, MA) had no significant ( $p>0.05$ ) effect on the juiciness of LD muscle samples.

Meat tenderness increased over the aging period, in particular in MA-packaged samples (significant differences between mean values in groups) (Table 5). Throughout the experiment, MA-packaged samples received higher $(p>0.05)$ average scores for tenderness than vacuumpackaged samples, which was reflected in average shear force values (Table 5).

In our study, the meat of male fallow deer was characterised by high sensory quality, which corroborates the findings of other authors who also investigated fallow deer meat (Tešanović et al., 2011; Bureš et al., 2015). A tendency towards an increase in tenderness, a decrease in shear force and juiciness of fallow deer meat during storage, noted in our study, was reported by Bureš et al. (2015) who analysed LD muscle samples collected from farm-raised male fallow deer, packaged under vacuum and stored at $4{ }^{\circ} \mathrm{C}$ for 21 days. In our study, slightly lower juiciness of stored meat samples, as compared with non-stored samples, was due to water loss over the aging period. The increase in tenderness and the decrease in shear force values, observed in fallow deer meat during aging, resulted from the activity of proteolytic enzymes ( $\mu$-calpain and m-calpain), which led to the degradation of cytoskeletal proteins responsible for maintaining the structural integrity of muscle fibers (Farouk et al., 2007).

\section{CONCLUSION}

The evaluated packaging systems (vacuum and MA composed of $40 \% \mathrm{CO}_{2}+60 \% \mathrm{~N}_{2}$ ) had no significant effect on the quality of fallow deer meat during chilled storage. However, vacuum-packaged meat samples were characterised by greater drip loss, which contributes to the growth of potentially pathogenic bacteria and negatively affects consumer appeal. The non-protein nitrogen content of the water extract of fallow deer meat increased over the aging period, pointing to progressive proteolysis, which contributed to an increase in tenderness and a decrease in water-holding capacity (natural and forced drip loss). Reduced natural and forced drip loss in stored meat resulted not only from changes in the water-binding capacity of proteins but also from water loss due to the loss of meat juices. The results of this study indicate that fallow deer meat stored at $2^{\circ} \mathrm{C}$ undergoes gradual undesirable changes in colour, water-holding capacity and juiciness.

\section{CONFLICT OF INTEREST}

We certify that there is no conflict of interest with any financial organization regarding the material discussed in the manuscript.

\section{ACKNOWLEDGMENTS}

The study was conducted with the use of laboratory equipment purchased under a research project funded by the European Regional Development Fund and the Ministry of Regional Development within the "Development of Eastern 
Poland 2007-2013” Operational Programme.

\section{REFERENCES}

AOAC (Association of Official Analytical Chemists). 1990 Official Methods for Analysis of Official Analytical Chemists. 15th edn. Association of Official Analytical Chemists, Arlington, VA, USA

Baryłko-Pikielna, N., T. Kossakowska, and Z. Baldwin. 1964. The selection of optimal method to prepare beef and pork for the sensoric evaluation. Annals of the Institute of Meat Industry 1:111-132.

Berruga, M. I., H. Vergara, and L. Gallego. 2005. Influence of packaging conditions on microbial and lipid oxidation in lamb meat. Small Rumin. Res. 57:257-264.

Bureš, D., L. Bartoň, R. Kotrba, and J. Hakl. 2015. Quality attributes and composition of meat from red deer (Cervus elaphus), fallow deer (Dama dama) and Aberdeen Angus and Holstein cattle (Bos taurus). J. Sci. Food Agric. 95:2299-2306.

Cayuela, J. M., M. D. Gil, S. Banón, and M. D. Garrido. 2004. Effect of vacuum and modified atmosphere packaging on the quality of pork loin. Eur. Food Res. Technol. 219:316-320.

CIE (Commision Internationale de l'Eclairage). 1978. Recommendations on Uniform Color Spaces-Color Difference Equations, Psychometric Color Terms. Supplement No. 2 to CIE Publication No. 15 (E-1.3.1.) 1978, 1971/(TC-1-3), CIE Publication, Paris, France.

Cifuni, G. F., A. Amici, M. Contó, P. Viola, and S. Failla. 2014. Effect of the hunting method on meat quality from fallow deer and wild boar and preliminary studies for predicting lipid oxidation using visible reflectance spectra. Eur. J. Wildl. Res. 60:519-526.

Daszkiewicz, T., D. Kubiak, R. Winarski, and M. KobaKowalczyk. 2012. The effect of gender on the quality of roe deer (Capreolus capreolus L.) meat. Small Rumin. Res. 103:169-175.

Dzierżyńska-Cybulko, B. 1963. Influence of temperature and storage time on biochemical and physicochemical parameters of beef. Studies in the Fields of Agriculture and Forestry 34:3-37.

Farouk, M. M., M. Beggan., S. Hurst, A. Stuart, P. M. Dobbie, and A. E. D. Bekhit. 2007. Meat quality attributes of chilled venison and beef. J. Food Qual. 30:1023-1039.

Faustman, C., Q. Sun, R. Mancini, and S. P. Suman. 2010. Myoglobin and lipid oxidation interactions: mechanistic bases and control. Meat Sci. 86:86-94.

Feidt, C., J. Brun-Bellut, and E. Dransfield. 1998. Liberation of peptides during meat storage and their interaction with proteinase activity. Meat Sci. 49:223-231.

Herring, H. K., J. H. Haggard, and L. J. Hansen. 1971. Studies on chemical and physical properties of pork in relation to quality. J. Anim. Sci. 33:578-589.
Honikel, K. O. 1998. Reference methods for the assessment of physical characteristics of meat. Meat Sci. 49:447-457.

Huff-Lonergan, E. and S. M. Lonergan. 2005. Mechanisms of water-holding capacity of meat: The role of postmortem biochemical and structural changes. Meat Sci. 71:194-204.

Hur, S. J., S. K. Jin, J. H. Park, S. W. Jung, and H. J. Lyu. 2013. Effect of modified atmosphere packaging and vacuum packaging on quality characteristics of low grade beef during cold storage. Asian Australas. J. Anim. Sci. 26:1781-1789.

ISO 8586 (International Organization for Standardization). 1993. Sensory Analysis; General Guidance for the Selection, Training and Monitoring of Assessors Part I: Selected Assessors; Part II Experts. (edn. 1) International Organization for Standardization, Geneva, Switzerland.

Jeremiah, L. E. 2001. Packaging alternatives to deliver fresh meats using short - or long - term distribution. Food Res. Int. 34:749772.

Mancini, R. A. and M. C. Hunt. 2005. Current research in meat color. Meat Sci. 71:100-121.

Okabe, Y., A. Watanabe, H. Shingu, S. Kushibiki, K. Hodate, M. Ishida, S. Ikeda, and T. Takeda. 2002. Effects of $\alpha$-tocopherol level in raw venison on lipid oxidation and volatiles during storage. Meat Sci. 62:457-462.

Pikul, J., D. E. Leszczyński, and F. A. Kummerow. 1989. Evaluation of three modified TBA methods for measuring lipid oxidation in chicken meat. J. Agric. Food Chem. 37:1309-1313.

Sekar, A., K. Dushyanthan, K. T. Radhakrishnan, and R. NarendraBabu. 2006. Effect of modified atmosphere packaging on structural and physical changes in buffalo meat. Meat Sci. 72:211-215.

Sørheim, O., R. Ofstad, and P. Lea. 2004. Effects of carbon dioxide on yield, texture and microstructure of cooked ground beef. Meat Sci. 67:231-236.

StatSoft Inc. 2011. STATISTICA (Data Analysis Software System), version 10. Tulsa, OK, USA.

Tešanović, D., B. Kalenjuk, D. Tešanović, D. Psodorov, Z. Ristić, and V. Marković. 2011. Changes of biochemical and sensory characteristics in the musculus longissimus dorsi of the fallow deer in the early phase post-mortem and during maturation. Afr. J. Biotechnol. 10:11668-11675.

Van Moeseke, W. and S. De Smet. 1999. Effect of time of deboning and sample size on drip loss of pork. Meat Sci. 52:151-156.

Van Oeckel, M. J., N. Warnants, and Ch. V. Boucqué. 1999. Comparison of different methods for measuring water holding capacity and juiciness of pork versus on-line screening methods. Meat Sci. 51:313-320.

Wiklund E., S. Sampels, T. R. Manley, J. Pickova, and R. P. Littlejohn. 2006. Effect of feeding regimen and chilled storage on water-holding capacity, colour stability, pigment content and oxidation in red deer (Cervus elaphus) meat. J. Sci. Food Agric. 86:98-106.

Zhou, G. H., X. L. Xu, and Y. Liu. 2010. Preservation technologies for fresh meat - A review. Meat Sci. 86:119-128. 